\title{
Industrialising the Southern African Development Community (SADC) Economies: Prospects and Challenges
}

\author{
John Bosco Nizeimana \\ Doctoral Student, Rhodes University, South Africa
}

Alfred G. Nhema

Department of Political and Administrative Studies, University of Zimbabwe, Zimbabwe

Received: January 7, 2016 Accepted: January 28, 2016 Published: January 29, 2016

doi: 10.5296/jsss.v3i2.8825 URL: http://dx.doi.org/10.5296/jsss.v3i2.8825

\begin{abstract}
This article examines the prospects and challenges of industrialisation as a tool for economic development in the Southern African Development Community (SADC) region. The economic importance of industrialisation is enshrined in its capacity to create job opportunities and facilitate synergies between and among various sectors of the economy. The paper posits that industrialisation is an engine for economic development that can promote sustainable positive social change in any given society. While the perceived view is that, in general, the industrialisation process in Africa has been disappointing; the Southern African Development Community (SADC) has committed itself towards embracing the concept of industrialisation as a tool for economic growth and development. Thus, given the historical failure of this concept on the African continent, it is important to analyse the prospects and challenges likely to be faced by the SADC region in their bid to hasten the industrialisation of their countries. Substantively, the paper relied on documentary research.
\end{abstract}

Keywords: Southern African Development Community (SADC), Industrialisation, Intra-regional trade, Economic growth

\section{Introduction and Background}

The need for economic growth and development in the Southern African Development Community (SADC) region through the industrialisation process is acknowledged as a 
process that is desirable if the region is to achieve sustainable economic and political stability.

The African continent has faced many challenges that encapsulate civil wars, economic and political instability. Given this environment, many of the African nations' attempts to industrialise have been disappointing. Since the 1990s, Africa's growth rate in the manufacturing industry has been below expectations (Zarenda, 2013). Overall, since the 1980 s, industrial output in Africa has actually declined in its share of global production (UNIDO report, 2009).

Given the above, it is prudent to examine how the SADC countries are trying to generate positive economic growth and development through the industrialisation process. The SADC region has committed itself to an industrialisation strategy as espoused in its $S A D C$ industrialisation strategy and roadmap (2015-2063) framework that was approved at the SADC summit meeting of April 2015 (SADC Secretariat Report, 2015). With the adoption of this policy strategy, attention is now on how SADC member countries will implement this industrialisation policy initiative.

The authors of this paper contend that if the concept of industrialisation is truly embraced, the region will become a benchmark for other regions on the continent. The paper further argues that the successful implementation of this industrialisation policy strategy by SADC member states will be based on its ability to bring about trade facilitation arrangements that will result in increased levels of intra-trade within the regional grouping and beyond. The central focus of the paper is to explore the prospects and challenges that face SADC countries in their bid to meet the objectives of the adopted industrialisation road map.

\section{Conceptual Analytical Framework}

\subsection{Industrialisation}

The concept of industrialisation entails the process in which a particular society, region or country transforms itself from being primarily an agricultural society into one based on the manufacturing of goods and services. In the process, basic manual production processes are substituted by mechanized ones (Szimai, 2009). One of the key features of industrialisation includes the use of technological innovation as a problem solving instrument with heavy reliance on the manufacturing sector. In brief, the notion of industrialisation is a transitional phase in which there is a gradual replacement of farming and resource extraction activities by the manufacturing and service sectors (Ibid, 2009). However, it is vital to note that this transition takes different forms at different times and places. This is significant in understanding the destiny of the Southern African region as it embarks on the industrialisation development path.

The term industrialisation dates back to the time of industrial developments in Europe in the early eighteenth and nineteenth periods. As noted by Crafts (1983), the beginning of the World War II was a phase that led to the industrialisation of European countries that resulted in the economic growth and development of large urban centres as well as conurbations. For example, the major technological breakthrough in textile production and the application of steam power to production in Great Britain in the second half of the eighteenth century had a deep impact on the industrialisation process in Europe in general (David, 1982). 


\section{MInstitute Macrothink}

Journal of Social Science Studies

ISSN 2329-9150

2016, Vol. 3, No. 2

The notion of industrialisation captures the introduction of fundamentally new production technologies that essentially affect the nature of production. Hence, in the process, the emergence of modern manufacturing leads to dramatic changes in the structure of the economy and a sustained increase in labour productivity and economic welfare. After Great Britain's achievements in industrialisation, the country became the technological leader in the world economy and this development automatically became a benchmark for other countries in Europe and the world at large. According to Pollard (1990), industrialisation became the main engine of accelerating economic growth in the $19^{\text {th }}$ century.

It is important to note that the industrialisation process in Europe had to rely on raw materials from the Global South, particularly Africa. Therefore, it is easy for the countries in the Global South to industrialise their economies because they have the raw materials that are the pre-requisites to the industrialisation process.

Thus, if the SADC region is to succeed in the industrialisation race, their raw materials must spearhead the process. The experience of European powers with industrialisation is an important element that should be acknowledged by SADC countries in their bid to embark on their own industrialisation processes. Significantly, for these countries to take off industrially, the process must be characterised by high levels of seriousness, commitments, willingness and smooth economic cooperation within member states. This will undoubtedly promote economic growth and subsequently lead to positive social change within the southern African region.

\subsection{Intra-Trade as a Concept}

For the past decades, the struggle for economic development in Africa has been dominated by the need for countries to regroup and work together in the name of regional economic integration. According to Edward (2011), inter-regional and international trade are important notions underlying the success of the fastest rising economies yet many countries continue to be isolated in the process and fail to achieve smooth and viable forms of integration. Inter-regional trade entails cross border economic cooperation. It is quite clear that countries that are successful in international trade have a large percentage of their trade within their regional groupings zone.

Of importance to note is that the intra-trade in SADC trade records rose as a share of total trade from US\$11.6bn in 2000 to US\$29bn in 2008. There has, however, been a decline of intra-regional trade from $22 \%$ of total trade in 2002 to less than $15 \%$ in 2008 . While the figure is still above the average intra-Africa trade of slightly over $10 \%$, SADC countries could do more if appropriate policies are put in place (Mbekeani, 2013).

\section{The Essence of Industrialisation in the SADC Region}

The SADC Industrialisation Strategy and Roadmap (2015-2063) was approved by the SADC Heads of state in April 2015. The main objective of the strategy is to transform the southern African region's economies through various measures aimed at enhancing the economic growth of the region. This therefore makes the industrialization strategy an instrumental tool that can be utilized to build a strong foundation for the economies of member countries.

The SADC Industrialisation Strategy and Roadmap (2015-2063) is a significant initiative that represents a multi-dimensional approach with a national, regional, continental and 
international focus. The plan is a modernization oriented strategy that, if wisely implemented is likely to promote sustainable economic growth for the region. (SADC Secretariat Report, 2015). Needless to mention, an important challenge to note is the fact that the success of this initiative is based on the ability of all SADC countries to have the necessary technological foundations to deal with the required changes in the productive sector. As noted in the SADC Secretariat Report (2015), the industrialization strategy requires earnest efforts aimed at enhancing technological setups and readiness, changes in the way of doing business, scaling-up productive capacity with a view to enhance economic inter linkages among member countries.

The SADC industrialisation strategy is an initiative that will enhance the beneficiation process that will result in most of the exported products being exported as finished products. Currently, in the agriculture sector, SADC countries continue to export unprocessed agricultural produce, earning approximately only $10 \%$ of the potential value of the products (SADC Secretariat Report, 2015).

The industrialisation roadmap in the Southern African region is a significant development whose benefits will lie in the manner in which the strategy will be implemented. In practice, industrialisation refers to a transfer of labour from low productivity agriculture to the high productivity industrial sector. This trajectory often results in the eventual increase in overall productivity and a rise in income per capita (Szimai, 2009). The more countries commit themselves in industrialising their economies, the more they expand their world markets for their manufactured products. The Southern African region harbours the much needed resources to back the industrialisation roadmap. However, this requires a strong determination and unity of purpose among member states in the region.

Practically, industrialisation is a powerful initiative that can move SADC countries out of their weak economic foundations. Many countries in the SADC region depend on agricultural earnings for their economic sustainability. However, scholars such as (Szimai, 2009) argue that productivity is higher in the industrial sector than in the agricultural sector. He also notes that the transfer of resources from agriculture to manufacturing provides an economic structural bonus. The importance of industrialisation lies not only in improving the economic status of the countries involved but also on creating a strong economic base for the targeted countries.

It cannot be denied that the industrialisation strategy adopted by the SADC countries will undoubtedly help to create a strong economic base for the region. According to Szimai (2009), the manufacturing sector offers more opportunities for capital accumulation than the dispersed agricultural sector. This is one of the reasons why the emergence of manufacturing has been so important in economic growth and development internationally.

\section{Industrialisation Challenges}

The industrialisation roadmap in the Southern African region is likely to be mired in the problem of overlapping membership of countries in the SADC region. Multiple memberships illustrate a lack of unity of purpose among member states. It is a major challenge which continues to weaken the prospects of having a successful industrialisation strategy. Almost half of COMESA members are also members of SADC. This tends to weaken and slow down 
the process of intra-SADC trade which is important for the industrialisation roadmap to be achieved.

According to Moreira (2005:21), of all SADC members, only Mozambique is not a member of other economic regional economic blocs. For example, Tanzania is a member of the East African Community (EAC), COMESA and also of SADC. This multiple membership scenario leads to costly competition, conflicts, inconsistencies in policy formulation and implementation, unnecessary duplication of functions, fragmentation of markets and restrictions in the growth potential of the sub region as a cohesive entity. Such situations tend to make it difficult for the successful implementation and administering of the different agreements as well as meeting the obligations of regional policies since the member states are not committed to only one regional bloc. When dealing with regional interests in negotiations, a country is bound to be mixed up on which particular different regional interests to represent.

It is our view that the successful implementation of industrialisation depends on the prospects of having improved intra-trade systems in the SADC region. For the industrialisation initiative to succeed, unity of purpose is very essential. However, the Southern African region has been characterized by the lack of political will within member states, especially on matters related to working together on economic projects.

If SADC member countries are to succeed with the industrialisation of their economies, efforts must be directed to the forging of a strong regional integration framework (Jenkins, 2000). Political willingness to forge a strong regional integration system is a necessary ingredient needed to spur intra trade and economic integration within the region as it creates a conducive environment for the industrialisation roadmap. Regional members will need to take a more realistic proactive approach that re-examines the countries' industrialization targets they have set for themselves. By doing so, better economic policies and structural reforms are likely be adopted and these will lead to improved macro-economic indicators, reduced inflation rates, fairer terms of trade, transparency and the opening up of the markets.

One major challenge likely to inhibit the successful implementation of the industrialisation roadmap in the Southern African region is related to existing bi-lateral cooperation agreement among member states. For example, the Free Trade Area Agreement (FTA) between South Africa and the European Union (EU) has had adverse effects in a number of SADC countries. As noted by Tsikata (1999), SADC has been more affected by the EU-SA FTA due to the fact that SADC is dominated by South Africa as the largest economy of the region as it represents more than $70 \%$ of the combined sub regional GDP and about $32 \%$ of its population. In the 1990s, subsidized European Union beef exports to South Africa that were introduced following the relaxation of quantitative controls displaced domestic and other suppliers within the SADC countries.

It must be emphasized that the Southern African's desire to industrialize their region is likely to be a success story in a corruption free environment. As noted in the SADC Regional Human Development Report (2000), corruption is an issue in some SADC countries. It is also a politically sensitive issue that is difficult to address. According to Jenkins (2000), the issues of bribery and corruption in Southern Africa have dominated the region; it is predominant at many customs check points in many parts of the region. Like in Mozambique, for example, 
customs services officials and other reports estimate that as much as $70 \%$ of imports are smuggled into the country. Reportedly, this occurs not because of high duty structures but because of delays in the processing of imports. It is reportedly more expensive to smuggle goods than pay the duty, but smuggling ensures that goods are delivered fast. Therefore, there is need to improve efficiency at borders to ensure that the government is not prejudiced through informal channels.

There is also a need for all SADC members to come together and adopt a trade monitoring and compliance mechanism for monitoring and eliminating any obstacles that may shield the tendency for corruption. This mechanism has the potential to facilitate movement of goods that can lead to increased intra-regional trade, thereby acting as a springboard for industrialising the SADC region.

Industrialised economies require a strong established transport infrastructure in the SADC member states. There is need to construct viable transportation networks, roads, railways, ports and airport facilities. Tackling these issues will not only facilitate intra-regional trade and international trade but will also create a conducive business environment for trade and the movement of goods in the region.

\section{Conclusion}

The successful implementation of the industrialisation roadmap in the SADC bloc will depend on the levels of intra-trade in the Southern African region. There is need for co-operative and collaborative efforts by all SADC member states to achieve the necessary industrialisation targets.

For the SADC region to succeed in the industrialisation process, major impediments such as corruption, multiple memberships, lack of political will, and poor implementation of trade protocols should be addressed first. This is largely because these challenges are, inter-alia, major contributing factors leading to poor levels of intra-trade in the region. Once some of these impediments are removed or at least reduced, there will be greater integration of all the SADC countries that will naturally spur the growth of intra-trade thereby creating a strong foundation for the industrialisation of the region.

\section{References}

Chauvin, S., \& Gaulier, G. (2002). Regional Trade integration in Southern Africa. Retrieved December 20, 2015, from http://www.cepii.org/PDF_PUB/wp/2002/wp2002-12

Crafts, N. F. R. (1983). Gross National Product in Europe, 1870-1910: Some New Estimates. Explorations in Economic History, (Vol. 20. pp. 387-401). http://dx.doi.org/10.1016/0014-4983(83)90026-8

Flatters, F. (2001). The SADC Trade Protocol: Impacts, Issues and the way ahead. Retrieved from http://qed.econ.queensu.ca/faculty/flatters/writings/ff_sadc_impacts.pdf

Edward, K. D. (2011). Protectionist Policy and Manufacturing Trade Flows in Africa. Tanzania; World Bank Publications.

Grusky, D. B. (1982). Industrialisation and the Status attainment Process: The thesis of industrialisation considered. Madison: University of Wisconsin.

Jenkins, C. (2001). New Forms of Cooperation and Integration in Emerging Africa: Integration 


\section{Macrothink}

Journal of Social Science Studies

ISSN 2329-9150

2016, Vol. 3, No. 2

and Co-operation in Southern Africa, OECD Development Centre Technical Papers, n 172.

Jenkins, C., Leape, J., \& Thomas, L. (2000). Gaining From Trade in Southern Africa: Complementary Policies to Underpin the SADC Free Trade Area. In C. Jenkins, J. Leape, \& L. Thomas (Eds.), MacMillan Press Ltd. http://dx.doi.org/10.1057/9780230523463

Kalenga, P. (1999). Regional Trade Integration in Southern Africa; A critical Political issues. Development Policy Research Unit: University of Cape Town.

Mbekeani. K. K. (2013). Intra-Regional Trade in Southern Africa: Structure, Performance and Challenges. NEPAD Regional Integration Policy Papers. No 2. Tunis: African Development Bank.

Moreira, H. (2002). Economic Integration and Third World Development. London: Greenwood Press.

Ncube, M., Issa, F., \& Audrey, Verdier-Chouchane. (Eds). (2007). Regional Integration and Trade in Africa. Cape Town: Trade Law Centre for Southern Africa.

SADC Secretariat Report. (2015). Sadc industrialisation strategy and roadmap (2015-2063). http://www.sadc.int/files/5314/3999/6455/SADC_Industrialisation_Strategy_Roadmap.pdf

Szimai, A. (2009). Industrialisation as an engine of growth in developing country, 1950-2005. Maastricht: UN-MERIT

Tsikata, Y. (1999). Southern Africa: Trade, Liberalization, and Implications for a Free Trade Area. Paper prepared for the Annual Forum of the Trade and Industrial Policy Secretariat, Muldersdrift.

Wim, N., Adam, S., \& Alejandro, L. (2013). Industrialisation lessons from BRICS: Comparative Analysis. IZADP, no 7543.

Zarenda, H. (2013). Deriving value from the Global Value Chain $(G V C)$ concept: An approach to regional industrial policies. Stellenbosch: Tralac.

\section{Copyright Disclaimer}

Copyright reserved by the author(s).

This article is an open-access article distributed under the terms and conditions of the Creative Commons Attribution license (http://creativecommons.org/licenses/by/3.0/). 